\title{
Green supply chain management and environmental performance among tea processing firms in Kericho County- Kenya
}

\author{
Benard Onyango Muma ${ }^{1}$, Richard Bitange Nyaoga ${ }^{1}$, Robert Bosire Matwere $^{2}$, Ednah Nyambega ${ }^{1}$ \\ ${ }^{1}$ Faculty of Commerce, Department of Accounting, Finance \& Management Science, Egerton University, Kenya \\ ${ }^{2}$ Faculty of Commerce, Department of Management Science, Kisii University, Kenya
}

\section{Email address:}

mumabenard@gmail.com (B. O. Muma),rnyaoga@yahoo.com (R. B. Nyaoga), matwerebosire@gmail.com (R. B. Matwere), eknyambega@gmail.com (E. K. Nyambega)

\section{To cite this article:}

Benard Onyango Muma, Richard Bitange Nyaoga, Robert Bosire Matwere, Ednah Nyambega. Green Supply Chain Management and Environmental Performance among Tea Processing Firms in Kericho County- Kenya. International Journal of Economics, Finance and Management Sciences. Vol. 2, No. 5, 2014, pp. 270-276. doi: 10.11648/j.ijefm.20140205.11

\begin{abstract}
The aim of this study was to investigate the effect of Green Supply Chain Management (GSCM) on Environmental Performance among tea processing firms in Kericho County. The study adopted a correlation study design. Data was collected from all the 32 tea processing firms in the County and analyzed using SPSS. Multiple regression model was developed and used to establish the effect of GSCM on Environmental Performance. ANOVA test was used to determine the statistical significance of the relationship between the variables. The results were presented using tables. The study established that GSCM has positive effect on environmental performance. The study therefore recommends that managements of tea processing firms and other manufacturing firms adopt GSCM practices in their supply chain operations. The study suggests that further studies should be conducted in processing firms other than tea processing firms. Further studies should also be conducted to relate GSCM with individual aspects of performance such as Economic, Environmental and Social Performance.
\end{abstract}

Keywords: Green Supply Chain Management, Organizational Performance, Tea Processing Firms

\section{Introduction}

There has been increasing environmental concern from the government and the general public in the recent past and even today. Much of this concern has been on the impact of corporate activities on the natural environment. This is due to the negative impacts some of these activities have on the environment such as global warming and scarcity of some critical resources. This has led to environmental management becoming a critical business consideration for any company that aims to survive from many regulations and tough business requirements (Yoon et al., 2010). Nimawat and Namdev (2012) argued that organizations and people must adopt environmentally responsible production and consumption in order to recover environmental quality, reduce poverty and bring about economic growth, with resultant improvements in healthy working conditions, and sustainability. Every organization including tea processing firms must put measures in place to ensure all dimensions of its operations are environmentally friendly.

According to Pietro et al. (2012), every organization must make better use of natural resources for sustainable growth. Every organization must incorporate environmentally friendly practices in all its activities. Just like other business activities, Supply Chain activities are no exception. Since the early 1990's, manufacturers have been forced to address Environmental Management in their supply chains (Wu et al., 2012). Being environmentally conscious in supply chain operations is not only associated with reduced negative impacts on the environment but also improvement in overall company performance (Green et al., 2012). While many organizations have in the past have concentrated on reverse logistics, there is need to adopt green supply chain management (GSCM) practices that looks at the entire supply chain. (Chang, 2013)

Dheeraj (2012) defined GSCM as the practice of 
monitoring and improving environmental performance in the supply chain by integrating environmental thinking into a supply chain management throughout a product's life cycle. As put forward by Manufacturing Research Centre of Michigan State University, GSCM ensures that every agent in the supply chain: suppliers, manufacturers, vendors and consumer and all the processes involved in the entire life of a product: material acquisition, processing, package, transportation and waste processing have no negative impact on the environment. (Bin \& Jun., 2009). This is achieved through total integration and coordination of all business processes: purchasing, manufacturing, marketing, logistics, and information systems and strategy alignment of customer focus, efficiency, quality, and responsiveness (Zelbst et al., 2009), and environmental sustainability (Green et al., 2012) throughout the supply chain.

\subsection{Statement of Problem}

GSCM in itself is not a new concept since literature has been developed in this area from as early as 1989 (Chien and Shih, 2007). However, this literature has not been broadly developed making it difficult to understand the relationship between GSCM and Environmental Performance. In Kenya, very limited research has been done to relate GSCM with Environmental Performance. Specifically, no such research has been done in the Tea processing industry. To enhance environmental conservation, tea processing firms have adopted green initiatives such as afforestation and re-afforestation, use of efficient energy sources and improved waste management. Despite these initiatives, there is continued outcry from environmental conservatists on environmental conservation and sustainable use of natural resources; long-standing concern about land degradation, deforestation and environmental pollution in general (Amemba et al, 2013). It is clear that there is need for further exploration on this area through research so as to bridge the existing gaps. This study aimed to bridge such gaps by exploring the effect of GSCM on Environmental Performance among Tea Processing Firms in Kericho County. In addition, this paper will add new knowledge to already existing literature; it will bring out an in-depth understanding of the effect of green supply chain management on environmental performance, especially for firms that have just started adopting these studies.

\subsection{Objectives of the Study}

The general objective of this study was to study the effect of GSCM on Environmental Performance among Tea Processing Firms in Kenya.

The study was guided by the following specific objectives: 1. To investigate the effect of Green Purchasing on Environmental Performance among tea processing firms in Kericho County

2. To establish the effect of Green Manufacturing on Environmental Performance among tea processing firms in Kericho County
3. To investigate the influence of Green Distribution on Environmental Performance among tea processing firms in Kericho County

4. To examine the effect of Green Marketing on Environmental Performance among tea processing firms in Kericho County

5. To investigate the influence of Reverse logistics on Environmental Performance among tea processing firms in Kericho County

\subsection{Research Hypothesis}

This study tested the following hypothesis;

Ho1: Green Purchasing has a negative effect on Environmental Performance among Tea Processing Firms in Kericho County

Ho2: Green manufacturing has negative effect on Environmental Performance among Tea Processing Firms in Kericho County

Ho3: Green distribution negatively affects Environmental Performance among Tea Processing Firms in Kericho County

Ho4: Green Marketing negatively affects Environmental Performance among Tea Processing Firms on Kericho County

Ho5: Reverse Logistics has negative effect on Environmental Performance among Tea Processing Firms in Kericho County

\section{Literature Review}

\subsection{Green Supply Chain Management}

Various researches have put forward various practices that can be used to achieve GSCM. Other researchers call them GSCM or activities. It is important to note that different organizations may adopt different GSCM practices depending on their operations and characteristics (Liu et al., 2011) and industrial sector (Huang et al., 2012).Dheeraj and Vishal, (2012) discussed four major practices of GSCM: green purchasing, green manufacturing and materials management, green distribution and marketing and reverse logistics. Ninlawan et al. (2010) on the other hand discussed green procurement, green manufacturing, green distribution, and reverse logistics. Similarly, Amemba et al. (2013) and Srivastava (2007) discussed green procurement, green manufacturing, green operations, reverse logistics and waste management as the major elements of GSCM. In this study, GSCM will be studied under green purchasing and inbound logistics, green manufacturing, green materials management, green distribution/marketing and reverse logistics.

\subsubsection{Green Purchasing}

Purchasing activities include vendor selection, material selection, outsourcing, negotiation, buying, delivery, scheduling, and materials management (Toke et al., 2010). Amemba et al. (2013) defined green purchasing as environmental purchasing involving activities such as reduction, reuse and recycling of materials (3Rs) in the process of purchasing. Toke et al. (2010) identified a number 
of initiatives that can be incorporated in the purchasing function to achieve environmental sustainability; organizations can develop Supplier Environmental Questionnaire to help in finding out suppliers' stance on Climate Change and related Environmental issues before selecting suppliers. Organizations can conduct Supplier Environmental Audits and Assessments to monitor supplier compliance to environmental standards and requirements. Other than the above initiatives organizations can opt for a participative approach to green purchasing by jointly developing cleaner technology and processes with their suppliers (Ninlawan et al., 2010)

\subsubsection{Green Manufacturing}

According to Nimawat and Namdev (2012), green manufacturing involves use of fast, reliable, and energy efficient production equipment aimed at eliminating wastes and improving productivity. It involves production processes that use inputs with minimal or reduced environmental impacts and which are highly efficient, and are associated with little or no waste or pollution (Amemba et al., 2013). Al-Odeh and Smallwood (2012) associated green manufacturing with clean production method, efficient technology, reduced raw materials and resources so as to reach low input, high output and low pollution while Amemba et al. (2013) advocated for use environmentally friendly energy sources like solar energy, recycling of raw materials and use biodegradable energy sources and materials in manufacturing operations.

\subsubsection{Green Distribution}

Manufactured products have to reach the market in time; the market has to be informed about the products' availability, their features and capabilities. This requires appropriate distribution and marketing systems. It is important that environmental concerns are taken care of by offering environmentally friendly products through environmentally friendly distribution and marketing system. Green distribution is achievable through; green packaging, green transportation and logistics (Nimawat and Namdev, 2012).

According to Ninlawan et al., (2010 Green packaging involves downsized packaging and use of green packaging materials. They also point out the need to cooperate with vendors to standardize packaging, encourage and adopt returnable packaging methods, promote recycling and reuse of packaging materials. The storage facility is another important aspect of green distribution. The storage facility should be capable of storing different categories of materials. In addition, the design and construction of storage facilities must meet the requirements of non-polluted environment, while strengthening maintenance of good humidity, corrosion, waterproofing among other factors (Zhang and Zheng, 2010). Key in distribution is transportation, According to Al-Odeh and Smallwood (2012), factors like: fuel, modes of transport, infrastructure, and operational practices are important factors to consider in developing green transportation.

\subsubsection{Green Marketing}

Al-Odeh and Smallwood, (2012) pointed out that achieving sustainable marketing needs keeping biological balance and pay more attention to environmental protection. The concept of green marketing tries to address these issues. It involves commitment of organizations to make sure their products and operations are environmentally friendly. According to Nimawat and Namdev (2012), green marketing is any marketing activity of an organization that aims at creating a positive effect or removes a negative effect of a particular product on the environment. It also brings an organization close to its clients, particularly clients with particular interest consumer rights and environment.

\subsubsection{Reverse Logistics}

According to Nimawat and Namdev (2012), reverse logistics refers to the role of logistics in product returns, source reduction, recycling, materials substitution, reuse of materials, waste disposal, repair and remanufacturing. It is a system for the recovery of used materials and products. Organizations can implement reverse logistics through recycling and waste logistics which can be established according to the actual need for the collection, classification, processing, packaging, handling, storage, and distribution to specialized treatment facility for processing (Zhang and Zheng, 2010). According to Olaf Schatteman (2013), reverse logistics involves the activities to avoid returns, to reduce materials in the forward system so as to reduce materials flow back and ensure reuse and recycling of materials.

\subsection{Environmental Performance}

ISO 14001 defines environmental performance as measurable results of the environmental management systems relating to the management of the environmental aspects performed by the organization based on its environmental policies and objectives (Gupta et al., 1998). It is focused on reduced levels of environmental pollutants (Green et al., 2012). Environmental performance of an organization may be achieved through reduction of air emission, reduction of waste water, reduction of solid wastes, decrease of consumption for hazardous materials, decrease of frequency for environmental accidents (Ninlawan et al., 2010). Environmental performance may be enhanced through among other factors assigning environmental responsibility to general managers, and they provide environmental training to non-environmental workers as well as environmental specialists (Dasgupta, 1997). Chien (2007) unlike other researchers looked at environmental performance in terms of favorable environmental policies and measures employed by the organization, operational performance, reduced emission and proper waste disposal.

\subsection{Empirical Literature}

Choi and Zhang. (2011) conducted a study on green logistics and business performance in China. They also found out that some organizations have found a match between environmental considerations and profitability. Otago (2009) argued in his findings on green supply management that GSCM helps reduce the ecological impacts of industrial activities thereby enhancing environmental performance. 
Green et al. (2012) developed a GSCM model focusing on GSCM practices implemented by manufacturing organizations. They wanted see whether the adoption of GSCM practices would improve environmental performance. In their findings, it was evident that GSCM had a positive contribution to environmental performance.

As discussed by Saman et al. (2012), Liu et al. (2011) in their study of green supply chain management in China found out a positive relationship between GSCM practices and environmental performances in all the three cases they studied. In these studies, they found out that market actor-oriented models are more sustainable for enhancing GSCM practices than regulation-oriented models as they are based on mutual communications and cooperation among the core stakeholders They suggested provision of more technical supports and application of market mechanisms other than the mandatory regulations in achieving GSCM. They further suggested production of environmentally friendly products through joint research and making it a requirement for suppliers to satisfy higher environmental standards as strategies for improving the involvement of external green supply chain management practices. It was noted that in all cases, companies entirely focus on the internally proactive environmental management activities because the external part is not implementable. Due to limited scope of their studies, they suggested further studies on interactions between GSCM practices and financial performance, business process and client services and dissemination of successful GSCM practices.

Hsu and $\mathrm{Hu}$ (2008) in their study on Green supply chain management in the electronic industry found out that establishment of an environmental database of products, asking for product testing report and top management support; GSCM practices can be attributed to environmental performance. In a study conducted by Chien and Shih (2007) on implementation of green supply chain management practices in the electrical and electronic industry and their relation to organizational performances, it was evident that green procurement and green manufacturing can generated favorable environmental performance.

\subsection{Theoretical Review}

This study appreciates the complexity theory of the organization. This theory considers an organization as a complex system composed of heterogeneous factors such as: customers, suppliers, general public, government, non-governmental international organizations etc. Implementation of green supply chain management requires participation and involvement of all the relevant and concerned parties (Sarkis, Zhu and Lai, 2010). Implementation of green supply management requires systems approach; understanding that an organization is a system of functional areas and external stakeholders and involving these parties in the implementation process (Choi and Krause, 2006). According to Sarkis, Zhu and Lai (2010), other theories that may enhance understanding of green supply include: ecological modernization theory that looks at innovation and technological development and their role in implementation of green supply chain management, information theory that focuses on the role of communication in implementation of green supply chain management, institutional theory that appreciates the role of external pressure on the organizational approaches to green supply chain management and stakeholder theory that acknowledges that external groups can influence or be affected by green supply chain management.

\section{Methodology}

\subsection{Research Design}

This study adopted a correlational research design. A correlational research investigates one or more characteristics of a group to discover the extent to which the characteristics vary together (Simon, 2011). The study sought to determine the effect of GSCM on Environmental Performance among tea processing firms in Kericho County. There are 32Tea Processing firms in Kericho County. Due to the small number of the firms, a census survey was adopted. From every firm, a factory manager and an environmental representative were given questionnaires. A total of 64 questionnaires were issued out to respondents.

\subsection{Data Collection}

Primary data were collected regarding GSCM and Environmental Performance using self-administered structured questionnaires. Factory production managers and environmental representatives who were considered to be informed on GSCM were used as the respondents for this study.

\subsection{Validity and Reliability}

The questionnaire items (questions) were developed to represent each variable in the research. A pre-test was done on the items and their measurement by checking the results obtained from the focus groups. Expertise opinions were also sought from lecturers and environmentalists. Reliability analysis seeks the extent to which a measurement procedure produces the same result if the process is repeated (Toke et al., 2012). To ensure data collection procedure is reliable, cronbach alpha coefficient was computed using SPSS. A value of 0.77 , higher than the threshold of 0.7 was obtained showing acceptable level of internal consistency.

\subsection{Data Analysis and Presentation}

The data collected was coded, and analyzed through SPSS version 21. A correlation analysis was conducted to establish the relationship between GSCM and Environmental Performance. A multiple regression analysis was used to test if Green Supply Chain management affects Environmental Performance. ANOVA test was then used to determine the level of significance of the effect of Green Supply Chain Management and Organizational Performance. The research findings were presented using tables. 


\section{Data Analysis, Empirical Results and Interpretation}

\subsection{Correlation Analysis}

A correlation analysis was conducted to establish the relationship between GSCM and Environmental Performance. Table 1 below shows the result from the table below, Pearson's correlation ( $\mathrm{r}$ ) indicates the correlation between the independent variables (GSCM) and dependent variable (Environmental Performance). The r value of 0.274 indicates a positive correlation between Green Purchasing and Environmental Performance. The first hypothesis was thus rejected and a conclusion was made that there is a positive relationship between Green Purchasing and Environmental Performance.

The $r$ value of 0.320 indicates a positive correlation between Green Manufacturing and Environmental
Performance. This led to the rejection of the second hypothesis and a conclusion that there is positive relationship between Green Manufacturing and Environmental performance. Similarly, Pearson's correlation value of 0.040 indicates a positive correlation between Green Distribution and Environmental Performance The third hypothesis was thus rejected and a conclusion made that there is positive relationship between Green Distribution and Environmental Performance. The $r$ value of 0.232 indicates a positive correlation between Green Marketing and Environmental Performance. The forth hypothesis was thus rejected and a conclusion made that there positive correlation between Green Marketing and Environmental Performance. Lastly, the value of $\mathrm{r}(0.298)$ shows existence of a positive correlation between Reverse Logistics and Environmental Performance. The fifth hypothesis was therefore rejected and a conclusion made that there is positive relationship between Reverse Logistics and Environmental Performance.

Table 1. Correlations analysis table

\begin{tabular}{|c|c|c|c|c|c|c|c|}
\hline & & $\begin{array}{l}\text { Green } \\
\text { Purchasing }\end{array}$ & $\begin{array}{l}\text { Green } \\
\text { Manufacturing }\end{array}$ & $\begin{array}{l}\text { Green } \\
\text { Distribution }\end{array}$ & $\begin{array}{l}\text { Green } \\
\text { Marketing }\end{array}$ & $\begin{array}{l}\text { Reverse } \\
\text { Logistics } \\
\end{array}$ & $\begin{array}{l}\text { Organizational } \\
\text { Performance }\end{array}$ \\
\hline \multirow{3}{*}{$\begin{array}{l}\text { Green } \\
\text { Purchasing }\end{array}$} & Pearson Correlation & 1 & $.425^{* *}$ & .117 & .018 & -.004 & .274 \\
\hline & Sig. (2-tailed) & & .005 & .456 & .908 & .978 & .075 \\
\hline & $\mathrm{N}$ & 43 & 43 & 43 & 43 & 43 & 43 \\
\hline \multirow{2}{*}{$\begin{array}{l}\text { Green } \\
\text { Manufacturing }\end{array}$} & Pearson Correlation & $.425^{* *}$ & 1 & .251 & $.345^{*}$ & .214 & $.320^{*}$ \\
\hline & Sig. (2-tailed) & .005 & & .105 & .024 & .169 & .037 \\
\hline \multirow{3}{*}{$\begin{array}{l}\text { Green } \\
\text { Distribution }\end{array}$} & Pearson Correlation & .117 & .251 & 1 & $.722^{* *}$ & .193 & .040 \\
\hline & Sig. (2-tailed) & .456 & .105 & & .000 & .215 & .799 \\
\hline & $\mathrm{N}$ & 43 & 43 & 43 & 43 & 43 & 43 \\
\hline \multirow{3}{*}{$\begin{array}{l}\text { Green } \\
\text { Marketing }\end{array}$} & Pearson Correlation & .018 & $.345^{*}$ & $.722^{* *}$ & 1 & $.352^{*}$ & .232 \\
\hline & Sig. (2-tailed) & .908 & .024 & .000 & & .020 & .134 \\
\hline & $\mathrm{N}$ & 43 & 43 & 43 & 43 & 43 & 43 \\
\hline \multirow{2}{*}{$\begin{array}{l}\text { Reverse } \\
\text { Logistics }\end{array}$} & Sig. (2-tailed) & .978 & .169 & .215 & .020 & & .052 \\
\hline & $\mathrm{N}$ & 43 & 43 & 43 & 43 & 43 & 43 \\
\hline \multirow{3}{*}{$\begin{array}{l}\text { Organizational } \\
\text { Performance }\end{array}$} & Pearson Correlation & .274 & $.320^{*}$ & .040 & .232 & .298 & 1 \\
\hline & Sig. (2-tailed) & .075 & .037 & .799 & .134 & .052 & \\
\hline & $\mathrm{N}$ & 43 & 43 & 43 & 43 & 43 & 43 \\
\hline
\end{tabular}

**. Correlation is significant at the 0.01 level (2-tailed).

*. Correlation is significant at the 0.05 level (2-tailed).

\subsection{Multiple Regression Analysis}

A multiple regression analysis was conducted to determine if GSCM affects Environmental Performance. The results were as shown in table 2.

Table 2. Multiple regression analysis for GSCM and Environmental Performance

\begin{tabular}{lllll}
\hline Model Summary & & & & \\
\hline Model & R & R Square & Adjusted R Square & Std. Error of the Estimate \\
\hline 1 & $.486^{\mathrm{a}}$ & .236 & .133 & .11200 \\
\hline
\end{tabular}

a. Predictors: (Constant), Reverse Logistics, Green Purchasing, Green Distribution, Green Manufacturing, Green Marketing

From table 2, $\mathrm{R}$ square value indicates the explanatory power of the regression model. It is the percentage of variance of the dependent variable (Environmental Performance) explained by the independent variables (Green Supply Chain Management). The value of 0.236 indicates that green supply chain management explains (affects) organizational performance to $23.6 \%$.

\subsection{ANOVA Test}

ANOVA test was conducted to test the statistical 
significance of the effect of GSCM on Environmental

Performance. The results were as shown in table 3

Table 3: Significance of the effect of GSCM on Environmental Performance

\begin{tabular}{lllllll}
\hline ANOVA table & & & & & \\
\hline Model & & Sum of Squares & Df & Mean Square & F & Sig. \\
\hline \multirow{3}{1}{1} & Regression & .144 & 5 & .029 & 2.290 & $.066^{\mathrm{b}}$ \\
& Residual & .464 & 37 & .013 & & \\
& Total & .608 & 42 & & & \\
\hline
\end{tabular}

a. Dependent Variable: Organizational Performance

b. Predictors: (Constant), Reverse Logistics, Green Purchasing, Green Distribution, Green Manufacturing, Green Marketing

From table 3, the significance value (p) of 0.066 gives the test on the entire model. Since the value of $p>0.05$, this implies that though there is positive effect of Green Supply
Chain Management on Environmental Performance, the effect is not have statistically significant.

\subsection{Table of Coefficients}

Table 4. Table of coefficients

\begin{tabular}{|c|c|c|c|c|c|c|}
\hline \multicolumn{7}{|c|}{ Table of Coefficients } \\
\hline \multirow{2}{*}{ Model } & & \multicolumn{2}{|c|}{ Unstandardized Coefficients } & \multirow{2}{*}{$\begin{array}{l}\text { Standardized Coefficients } \\
\text { Beta }\end{array}$} & \multirow{2}{*}{ t } & \multirow{2}{*}{ Sig.(p) } \\
\hline & & B & Std. Error & & & \\
\hline \multirow{6}{*}{1} & (Constant) & .702 & 1.020 & & .688 & .496 \\
\hline & Green Purchasing & .252 & .166 & .247 & 1.514 & .139 \\
\hline & Green Manufacturing & .162 & .210 & .133 & .771 & .445 \\
\hline & Green Distribution & -.204 & .148 & -.293 & -1.385 & .174 \\
\hline & Green Marketing & .321 & .231 & .317 & 1.390 & .173 \\
\hline & Reverse Logistics & .295 & .213 & .216 & 1.388 & .173 \\
\hline
\end{tabular}

a. Dependent Variable: Organizational Performance

Table.4 shows the significance (p) values for each independent variable (green supply chain management). $\mathrm{P}$ value of $p<0.05$ shows that the independent variable is a predictor of the dependent variable. Significance value $(p)$ of 0.139 shows that the effect of green purchasing on environmental performance is statistically insignificant, significance value (p) of 0.445 shows that the effect of green manufacturing on environmental performance is statistically insignificant and significance value (p) of 0.174 shows that the effect of green distribution on environmental performance is statistically insignificant. Similarly, significance value (p) of 0.173 and 0.173 shows that green marketing and reverse logistics have statistically insignificant effect on environmental performance. Most tea processing firms started serious adoption of green supply chain management in the recent past, some as recent as 2005. It is important to understand the effect on environmental performance that can be attributed to green supply chain management so far.

From the findings, the equation for the regression model can be given by;

$\mathrm{Y}=0.702+0.247 \mathrm{X}_{1}+0.133 \mathrm{X}_{2}-0.293 \mathrm{X}_{3}+0.317 \mathrm{X}_{4}+$ $0.21 \mathrm{X}_{5}+\varepsilon$

Where; Y - Organizational Performance

$\beta 0$ - Constant

$\beta_{1}-\beta 5$ - Regression coefficients

$\mathrm{X}_{1}$ - Green Purchasing

$\mathrm{X}_{2}$ - Green Manufacturing

$\mathrm{X}_{3}$ - Green Distribution

$\mathrm{X}_{4}$ - Green Marketing
$\mathrm{X}_{5}$ - Reverse logistics

$\varepsilon$ - Error term

\section{Conclusion and Recommendations}

\subsection{Conclusions}

Based on the findings of the study, the following conclusions were made: There is positive relationship between Green Supply Chain Management Practices; Green Purchasing, Green Manufacturing, Green Distribution, Green Marketing and Reverse Logistics and Environmental Performance. From the regression analysis it was concluded that Green Supply Chain Management has a positive effect on Environmental Performance. Organizations that adopt green supply chain management practices experience reduced environmental pollution and reduced cost of environmental management thereby enhancing their environmental performance. However, the effect of green supply chain management on environmental performance is statistically insignificant. This result could be attributed to the fact that most tea processing firms started adoption of adopting green supply chain strategies in the recent past and the effects of these practices may not have fully been realized. The study therefore recommends that: tea processing firms and other manufacturing firms should consider adopting green supply chain management practices. They should embrace green strategies in their purchasing, manufacturing, distribution, marketing and reverse logistics operations. 


\subsection{Recommendations for Further Study}

Areas of further study that were identified in this study include: Studies in other processing firms other than tea processing firms, studies to relate GSCM with other aspects of performance such as economic and social performance and studies to explore other GSCM practices other than green purchasing, green manufacturing, green distribution, green marketing and reverse logistics.

\section{References}

[1] Al-Odeh, M \&Smallhood, J. (2012). Sustainable Supply Chain Management: Literature Review, Trends, and Framework. International Journal of Computational Engineering \& Management. 15(1) 85-90

[2] Amemba, C. S., Nyaboke, P. G., Osoro, A. \&Mburu, N. (2013).Elements of Green Supply Chain Management. European Journal of Business and Management. 5(12) 51-61

[3] Bin, H.\& Jun, Y. (2009).An Analysis on Green Supply Chain Management in E-Commerce Under the Economic Globalization.2009 International Conference on Business Intelligence and Financial Engineering, 2009

[4] Chang, B. Y., Kenzhekhanuly, Y. \& Park, B. (2013).A Study on Determinants of Green Supply Chain Management. International Journal of Control and Automation 6, (3), 199-208

[5] Chien, M. K. \& Shih, L. H. (2007).An empirical study of the implementation of green supply chain management practices in the electrical and electronic industry and their relation to organizational performances Int. J. Environ. Science and Technology., 4 (3)383-394

[6] Choi, T.Y., Krause, D.R., 2006. The supply base and its complexity: Implications for transaction costs, risks, responsiveness, and innovation. Journal of Operations Management, 24(5), 637-652.

[7] Dasgupta, S., Hettige, H. \& Wheeler D. (1998). What improves environmental performance? Evidence from Mexican industry. Policy Research Working Paper Series. The world Bank

[8] Dheeraj, N. \& Vishal, N. (2012).An Overview of Green Supply Chain Management in India Research Journal of Recent Sciences 1(6)77-82

[9] Green, K.W., Pamela, Z., Meacham J. \&Bhadauria, S. V. (2012). Green Supply Chain Management Practices: Impact on Performance. Supply Chain Management: An International Journal, 17(3)290-305
[10] Huang, X., Tan, B. L. \& Ding X. (2012).Green Supply Chain Management Practices: A Sectoral Investigation into Manufacturing SMEs in China. International Conference on Economics, Business and Marketing Management.147-151 (2012) IACSIT Press, Singapore

[11] Ninlawan, C., Seksan P., Tossapol K., \& Pilada W. (2010). The Implementation of Green Supply Chain Management Practices in Electronics Industry. Proceedings of the International Multi Conference of Engineers and Computer Scientists, 17-19 March 2010 Hong Kong

[12] Olaf S. (2013). Reverse Logistics. Retrieved from https://www.ashgate.com/pdf/SamplePages/ghsupplych2.pdf\# page $=1 \&$ zoom $=$ auto, $0,-22$ on $5^{\text {th }}$ August 2014 .

[13] Pietro, E., Huge-Brodin, M., Isaksson, K. \& Sweeney, E. (2012).Purchasing Green Transport and Logistics Services: Implications for Small Business. National Institute for Transport and Logistics

[14] Saman, Aslinda, N. Seman, A.Zakuan, N., Jusoh, A., Shoki, M \&Arif, M. (2012). Green Supply Chain Management: A review and research direction. International Journal of Managing Value and Supply Chains, 3 (1)

[15] Sarkis, J., Zhu, Q. and Lai, K. (2010). An Organizational Theoretic Review of Green Supply Chain Management Literature. Working Paper No. 2010-11

[16] Srivastava, S. K. (2007). Green supply-chain management: a state-of-the-art literature review. International Journal of Management Reviews, 9 (1), 53-80

[17] Toke, L.K., Gupta, R.C. and Dandekar, M. (2012).An empirical study of green supply chain management in Indian perspective. International Journal of Applied Sciences and Engineering Research 1(2)372-383

[18] Wu, J., Dunn, S. \& Forman, H. (2012).A Study on Green Supply Chain Management Practices among Large Global Corporations. Journal of Supply Chain and Operations Management 10(1)182-194

[19] Yoon, S. C. \& Chang, H. O. (2010).Green Logistics Management School of Air Transport, Transportation and Logistics, Ubiquitous Technology Application Research Center, Korea Aerospace University

[20] Zelbst, P. J., Green, K. W., Sower, V. E., \& Reyes, P. (2009).Impact of Supply Chain Linkages on Supply Chain Performance. Industrial Management \& Data Systems, 109 (6), 665-682.

[21] Zhang, J. \& Zheng, L. (2010) Research on the Building of Green Logistics System and the Development Strategy in Jilin Province International Conference, Logistics engineering and management, 8-10 October(2010) American Society of Civil Engineers, Chengdu, China 